\title{
WORKING-CAPITAL FINANCING OF SMALL BUSINESS
}

\author{
Victor L. Andrews, * Seymour Friedland, † and Eli Shapiroł
}

\section{INTRODUCTION}

There are several important suppliers of short-term funds ${ }^{1}$ in our financial system. The means used by small concerns to secure short-term financing are associated closely enough with the institutional practice of these lenders that, in large part, the two must be considered together. Therefore, this discussion concentrates upon the financial relationships between small businesses and (I) the commercial banking system, (2) other financial intermediaries, (3) business firms in their lending activities, and (4) specialized financing institutions.

\section{The Denand for Short-Term Funds}

There are strong incentives for business to finance short-term assets with shortterm funds and permanent assets with long-term funds. ${ }^{2}$ Lack of access to external long-term debt and equity sources, however, compels small businesses to substitute short-term funds where long-term funds would be preferred. Thus, many small firms are forced to finance permanent assets by continuously refunding short-term debt. ${ }^{3}$

* A.B. I95I, M.A. I953, M.B.A. 1954, University of Chicago; Ph.D. 1958, Massachusetts Institute of Technology. Assistant Professor of Finance, School of Industrial Management, Massachusetts Institute of Technology. Contributor to economics publications.

†B.S. 1950, M.B.A. I951, Boston University; Ph.D. 1955, Harvard University. Assistant Professor of Finance, School of Business, Rutgers University. Contributor to economics publications.

† A.B. 1936, Brooklyn College; A.M. 1937, Ph.D. 1945, Columbia University. Professor of Finance, School of Industrial Management, Massachusetts Institute of T'echnology. Research Staff, National Bureau of Economic Research. Author, [with others] Personal Finance Industry and Its Credit Standards (1939), [with W. H. Steiner] Money and Banking (I941, r953), Development of Wisconsin Credit Union Movement (1947). Contributor to economics publications.

I There is a terminological difficulty inherent in the distinction between short-term financing and financing the total of current assets. Normally, a firm's gross current assets exceed its current liabilities. Necessarily, then, the difference is financed from long-term sources. Since long-term financing lies outside the scope of this paper, we do not discuss this matter. Therefore, it should be understood that short-term financing or working-capital financing here refers to the use of total short-term liabilities to finance a part of current assets.

${ }^{2}$ For representative statements of this notion, sec Bion B. Howard \& Miller Upton, Introduction to Business Finance 3 ro-I4 (I953); Harry G. Guthman \& Herbert E. Dougali, Corporate Financial Policx $386-87$ (3d ed. r955).

This observation is substantiated by the results of a survey of member-bank loans to businesses in the Fourth Federal Reserve District. In industries in which small businesses tend to predominate, there was a heavy concentration of continuous borrowing from banks. Thus, in this survey, while only one-third of the amount of notes was over one year old, nearly two-thirds of the dollar volume of commercial and industrial loans was outstanding to borrowers who had been continuously in debe on such loans to the same banks for one year or more. See Continuous Borrowing Through "Short-Term" Bank Loath, Monthly Business Review of the Federal Reserve Bank of Cleveland, Sept. 1956, p. 6. 
A. Industry Factors in Short-Term Financing

Where technology requires heavy investment by individual firms in fixed assets, the industry is characterized by a high fixed to total asset ratio and a parallel high proportion of long-term funds in the financial structure. Needs for short-term financing are minimal. Conversely, in other industries with less plant and equip-

TABLE I

Cumulative Percentage Distribution of the Number of Concerns in Selected Industries by Size Class ${ }^{1}$

\begin{tabular}{|c|c|c|c|c|c|}
\hline \multirow[b]{2}{*}{ Industry } & \multicolumn{5}{|c|}{ Nunien UNDER Assets Cuass (thousands of dollars) } \\
\hline & 50 & 100 & 250 & 1,000 & 5,000 \\
\hline 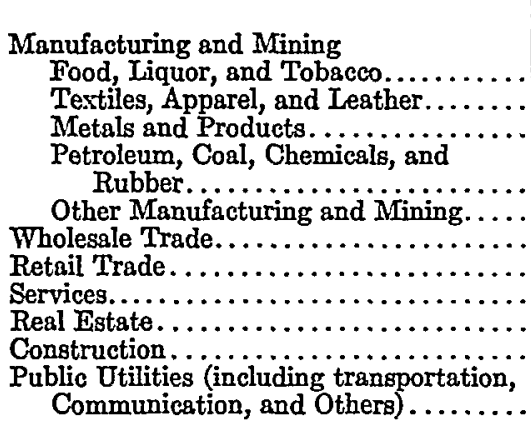 & $\begin{array}{l}59.6 \\
60.0 \\
47.6 \\
73.3 \\
81.9 \\
74.6^{*} \\
90.8^{*} \\
97.0^{*} \\
68.7^{*} \\
92.3^{*} \\
93.3^{*}\end{array}$ & $\begin{array}{l}75.7 \\
75.3 \\
66.1 \\
80.2 \\
89.0 \\
84.1 \\
96.5 \\
98.8 \\
77.3 \\
95.4 \\
95.8\end{array}$ & $\begin{array}{l}\text { Per cent } \\
\\
86.4 \\
86.5 \\
79.7 \\
\\
89.0 \\
94.5^{*} \\
93.9^{*} \\
99.1 \\
99.6 \\
90.9^{*} \\
98.6 \\
98.3\end{array}$ & $\begin{array}{l}95.7^{*} \\
96.0^{*} \\
92.2 \\
95.9 \\
98.4 \\
98.8 \\
99.9 \\
99.9 \\
98.4 \\
99.7 \\
99.3\end{array}$ & $\begin{array}{r}99.0 \\
99.2 \\
97.7^{*} \\
98.8^{*} \\
99.7 \\
99.8 \\
100.0 \\
100.0 \\
99.8 \\
100.0 \\
99.8\end{array}$ \\
\hline
\end{tabular}

*Denotes proportion in each industry defined as "small."

1Sales finance companies were included in original data, but are omitted here.

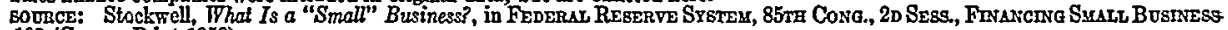
150, 102 (Comm. Print 1958).

TABLE II

Cumulative Percentage Distribution of Total Assets of Concerns in Selected INDUSTRIES BY Size CLASS

\begin{tabular}{|c|c|c|c|c|c|}
\hline \multirow[b]{2}{*}{ Industry } & \multicolumn{5}{|c|}{ Assets UNDER Assets Cr.ASS (thousands of dollarB) } \\
\hline & 50 & 100 & 250 & 1,000 & 5,000 \\
\hline 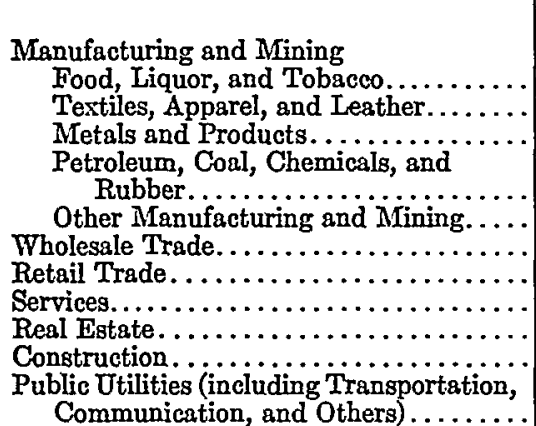 & $\begin{array}{l}1.4 \\
2.8 \\
.6 \\
.4 \\
6.7 \\
6.0^{*} \\
29.9^{*} \\
34.7^{*} \\
12.7^{*} \\
18.2^{*} \\
1.3^{*}\end{array}$ & $\begin{array}{r}3.5 \\
6.4 \\
1.6 \\
.9 \\
11.2 \\
13.0 \\
44.7 \\
45.7 \\
18.1 \\
26.7 \\
1.9\end{array}$ & $\begin{array}{c}6.7 \\
12.3 \\
3.3 \\
2.2 \\
17.3^{*} \\
28.7^{*} \\
59.1 \\
57.1 \\
33.7^{*} \\
45.8^{*} \\
3.2\end{array}$ & $\begin{array}{r}15.1^{*} \\
27.5^{*} \\
8.0 \\
5.3 \\
29.9 \\
51.6 \\
71.6 \\
71.2 \\
57.7 \\
65.4 \\
4.9\end{array}$ & $\begin{array}{l}27.6 \\
48.9 \\
17.2^{*} \\
11.0^{*} \\
48.5 \\
71.6 \\
79.7 \\
83.2 \\
80.6 \\
82.1 \\
7.8\end{array}$ \\
\hline
\end{tabular}

*Denotes proportion in each industry defined as "small."

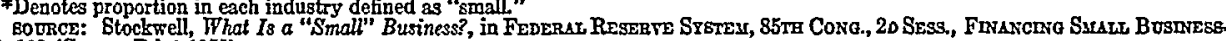
150, 162 (Comm. Print 1958). 
ment, the ratio of current to total assets is higher, and a correspondingly greater need for short-term financing results.

Seasonal operations give rise to a demand for short-term funds in many industries. As seasonal needs to carry inventories or extend credit strain cash resources, for example, managers meet these needs with short-term borrowing, which can be readily reduced as the need subsides.

In examining the industrial structure of small businesses in order to gain insights into the effect of their operations and the need for short-term financing, we will use the size and industry classification developed by the Federal Reserve Board for the most recent (October 1957) survey of member-bank loans to business. Table one is a percentage distribution of the number of firms classified by asset size. Table two shows the distribution of assets in each industry among firms in the various size classes. Together, these tables provide an admittedly rough indication of the industries in which the "small" firm is quantitatively important.

These tables illustrate the need for distinguishing the influence upon the demand for funds exerted by the nature of the asset structure of firms within industries and the quantitative significance of small firms within the same industries. For example, in public utilities (including transportation and communication here), heavy plant and equipment requirements make long-term financing the primary demand for funds. Moreover, partly as a result of the need for large-scale operation of heavy fixed investment, small firms are a quantitatively unimportant component of the industry, as indicated in table two. On both counts, then, utilities are not important for the subject of this paper. In distinction, small firms account for thirty-four per cent of the real estate industry's assets, but their asset requirements do not pose particular needs for short-term financing. Typically, real estate firms have a high proportion of fixed to total assets. These assets serve as security for long-term loans, and the financial needs of these firms are fulfilled in this way. Thus, although small firms are significant in the industry, they have no important need to draw upon sources of short-term funds.

Small firms in the trade industry are the largest single group of firms for which a relatively large amount of working-capital financing is consistently needed. Concentration of firms and assets in the lower size brackets is heavy in the trade industry. Almost ninety-one per cent of the firms holding thirty per cent of the assets in the retail trade fall in the $\$ 50,000$-and-under asset class, defined by the Federal Reserve Board as small for the industry. The $\$ 250,000$-and-under bracket includes ninety-nine per cent of retail firms, and in the aggregate, they possess fifty-nine per cent of the industry's assets. In the wholesale trade, small firms of less than $\$ 250,000$ of assets

" "Small" here is as defined by the Federal Reserve Board. A primary steel producer is much larger in terms of absolute volume of assets than a haberdasher; yet, both firms may be small in comparison with other firms in their respective industries. The Federal Reserve Board attempted to account for this by designating different asset-size classes as "small" in each industry. These are indicated in the tables. See Stockwell, What Is a "Small" Business?, in Federat Reserve System, 85TH Cong., 2D Sess., Financing Small Business, 150, 158-63 (Comm. Print 1958) [hereinafter cited as Federal Reserve REPORT]. 
held twenty-nine per cent of the industry's assets. Though these tables do not make the comparison, the number of firms in the trade industry bulks large in the business population. Firms in the retail trade made up almost forty-two per cent of the 4,300,000 firms in operation in 1957; and the wholesale trade accounts for another seven per cent. ${ }^{5}$ Together, they constitute slightly less than half the entire business population. Thus, roughly one-half of the business population consists of firms for which working-capital financing is quantitatively important.

Demands for short-term funds are subject to seasonal influences in the trade industry. Retail firms especially are affected by holiday influences and the sale of goods connected with seasonal weather changes-for example, clothing, sporting goods, vacation items, and food consumed at certain times of the year.

In general, fixed asset needs are limited in the trade industry, especially the retail segment. Inventory and accounts receivable comprise a large fraction of total assets, and both are financed, in large part, on a short-term basis. We do not have statistics regarding the proportion of accounts receivable in the trade industry to all of nonfarm businesses' accounts receivable, but we do have the figure for inventories. In July 1958 , nonfarm business inventories amounted to $\$ 85,900,000,000 .^{6}$ Inventory of the retail trade and wholesale trade amounted to $\$ 24,000,000,000$ and $\$ 12,100,000,000$, respectively, on this date. Since small firms are significant in terms of total assets, it follows that they account for much of this inventory and that their demands for its financing constitute a large part of the demand for short-term funds.

The financing of short-term assets in manufacturing and mining varies among the components of the industry. It is clear that in the aggregate, financing this industry's inventory gives rise to a significant demand for short-term funds, since at the end of July 1958 , manufacturing inventories were $\$ 49,800,000,000$ of a total of $\$ 85,900,000,000$ of nonfarm inventories. ${ }^{7}$

Large-scale operation in petroleum, coal, chemicals, and rubber tends to concentrate the industry's assets in large firms. Small firms hold only eleven per cent of total assets, as shown in table two, and, moreover, a low proportion of short-term to total assets minimizes short-term financing needs within individual firms. In other lines of manufacturing, small firms are more important. Small firms in textiles, apparel, and leather account for over twenty-seven per cent of industry assets. Small firms held seventeen per cent of industry assets in the metals and metal products and "other" lines of manufacturing. In food, liquor, and tobacco, they held fifteen per cent of total assets; the asset structure of the latter gives rise to short financing needs.

The services industry is comprised mostly of firms in the smallest size category which possess nearly thirty-five per cent of the industry's assets. Many firms in the services industry center their operations about personal services and, as a result,

${ }^{5}$ Growth in Operating Business Concerns in First Half of 1957, Survey of Current Business, Jan. 1958, p. 6.

Survey of Current Business, Sept. 1958, p. S-3.

Ibid. 
need not finance a substantial volume of inventory; an accumulation of accounts receivable, however, may "freeze" a substantial portion of a service firm's funds. Their dependence on short-term financing is evidenced by the industry's high proportion of the number of loans outstanding from the banking system.

Small construction firms account for eighteen per cent of the industry's assets. The construction industry borrows substantially from the commercial banking system.

Small firms tend to utilize short-term loans intensively, in part because of their asset structure. Given two different-sized firms, with a similar proportion of fixed and current assets, the large firm will typically have an advantage in securing longterm funds, because its future income will appear more certain. The small firm, however, has an equal opportunity to secure short-term funds by offering its tangible and assessable current assets as security for these loans, and the practices of the financial system center about the use of this security for loans.

II

\section{Who SUPPLIES Short-TERM Funds?}

The structure of suppliers of short-term funds is the product of long and continuing evolution in the financial markets. The newer institutions and forms of working-capital financing discussed below are in the forefront of a continuous proliferation in the sources of funds. The commercial banking system is the oldest institutional supplier and today remains the largest single source among these suppliers. Other major suppliers have grown to fill gaps left by the banking system. As the commercial banks indicated unwillingness or inability to assume the risks and administrative costs inherent in certain types of lending, especially to small business, other lenders fitted to absorb these risks and deal effectively with costs of loan management moved in to provide funds.

An essential feature of the growth of new suppliers is their ability to draw upon a range of financial sources in the capital and money markets not available to small industrial borrowers or, if available, to draw upon them on terms more advantageous than the borrower could secure directly. Small firms may be excluded entirely or, if not excluded, must pay higher rates in the financial markets than do large firms and specialized financial institutions. This is explicable in terms of the market's assessment of risk and costs of lending, but it invites arbitrage. Thus, some creditors exploit interest-rate differentials by acquiring funds cheaply and supplying credit on terms better than the market would afford the small borrower. In effect, lenders interpose their credit standing between the financial markets and the industrial borrowers.

The small firm chooses among the alternatives available to it, and through its selection of the most favorable combination of cost and contract terms, encourages growth and efficiency in the financial mechanism. In this way, the history of the financial markets has been one of increasing diversity in the sources and methods of 
business finance, with the system continually trying out innovations, accepting some, discarding others. ${ }^{8}$

For interposition to work, it is necessary that some creditors appraise the small firm more favorably than does the over-all funds market. Several things give rise to such divergent views. Experience and familiarity may lead to a favorable credit appraisal. For example, a local bank may have better information than a "foreign" bank about the quality of management or the market prospects of a small business, thereby making the lending risk involved appear smaller than from a distance. This accounts for the local character of bank credit markets for firms which do not have a prime credit standing. In a similar way, a financial institution may have considerable experience in making loans to a particular industry. As a result, it is more willing to lend to a small firm in the industry than would other creditors. A factor which encourages trade creditors to view small firms as credit-worthy is the potentiality of additional operating profits which results from extending credit, and thereby expanding output and sales.

In addition, a variety of lending practices have been developed which reduce risk in the small business loan. These include loans secured by very salable inventory and the financing of accounts receivable. These devices have been associated particularly with the growth of commercial finance companies.

\section{A. Financing through Commercial Banks}

Within the constraints of risk and the expense of loan administration, commercial banks, as a rule, cultivate small business accounts. The incentives for them to do this are numerous. Accommodation of the financial needs of small business provides an opportunity for expansion of the deposit resources of the bank and a resulting enhancement of its earning capacity. Small businesses are, in the aggregate, big customers, and many are good credit risks. Indeed, many bankers insist that size of borrower has little bearing in lending decisions. ${ }^{9}$

A distribution by size of borrower of the business loans of the member banks of the Federal Reserve System at October $x 957$ is contained in table three. Businesses had a total of $I, 300,000$ loans outstanding, totaling $\$ 40,600,000,000$. The number and dollar volume of loans was unevenly distributed between sizes of borrowers. Firms of less than $\$ 250,000$ in assets had taken over three out of four loans outstanding then, but the volume was $\$ 6,800,000,000$, or only 16.5 per cent of the total. Concerns with assets in excess of $\$ 25,000,000$ had drawn on the banks for less than one per cent of the number, but over one-third the dollar volume.

\section{Maturity of loans}

The bulk of small business' borrowing from the commercial banks had a maturity of less than one year. In October 1957 , for example, fifty-four per cent of the loans to businesses of less than $\$ 50,000$ assets were short-term; in the $\$ 50,000-\$ 250,000$ cate-

${ }^{8}$ This evolution is well outlined in N. H. Jacoby and R. J. Saulnier, Business Finance and Banking (1947).

${ }^{8}$ Eastburn and Balles, Commercial Banks, in Federal Reserve Report 396, 402. 
TABLE III

Business Loans of Member Banks by Size of Borrower, October 1957

\begin{tabular}{|c|c|c|c|c|}
\hline \multirow[b]{2}{*}{$\begin{array}{c}\text { Size of Borrower (total assets, in } \\
\text { thousands) }\end{array}$} & \multicolumn{2}{|c|}{ AMOUNT OF LOANS } & \multicolumn{2}{|c|}{ NuLIBER OF LOANS } \\
\hline & $\begin{array}{r}\text { Billions of } \\
\text { dollars }\end{array}$ & $\begin{array}{c}\text { Percentage } \\
\text { Distribution }\end{array}$ & Thousands & $\begin{array}{l}\text { Percentage } \\
\text { Distribution }\end{array}$ \\
\hline 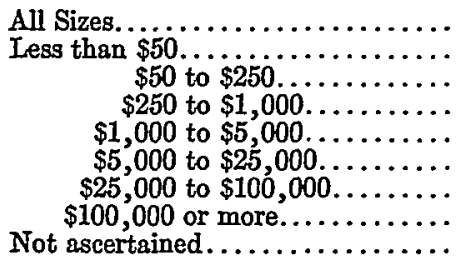 & $\begin{array}{r}\$ 40.6 \\
1.5 \\
5.3 \\
6.3 \\
6.7 \\
5.9 \\
4.9 \\
8.8 \\
1.2\end{array}$ & $\begin{array}{r}100.0 \\
3.6 \\
12.9 \\
15.5 \\
16.7 \\
14.6 \\
12.0 \\
21.7 \\
3.0\end{array}$ & $\begin{array}{r}1,280.6 \\
504.7 \\
494.3 \\
157.6 \\
48.2 \\
13.3 \\
5.4 \\
6.5 \\
50.7\end{array}$ & $\begin{array}{r}100.0 \\
39.4 \\
38.0 \\
12.3 \\
3.8 \\
1.0 \\
.4 \\
.5 \\
4.0\end{array}$ \\
\hline
\end{tabular}

1Detail may not add to totals because of rounding.

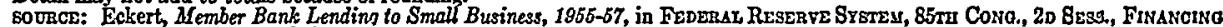
Buam Business 371, 375 (Comm. Print 1958).

gory, sixty-three per cent of loans were short-term loans. These percentages were somewhat lower than the corresponding ones for intermediate-size businesses. Small businesses tend to draw more heavily on the banking system for term loans than do the medium-size corporations, which have access to the capital markets. The largest firms duplicate the tendency of small businesses to use the banks for term loans, but on a different basis. Whereas small businesses resort to term loans because they lack alternatives, large borrowers frequently use this form of financing, on an interim basis, as a source of flexibility in the timing of their issues of long-term securities.

\section{Secured loans and the forms of bank lending}

Large concerns typically borrow from banks on an unsecured basis. The generally lower credit standing of small businesses has led to the development of an extensive variety of loans which incorporate some form of security for the lending bank. In large measure, the possession of suitable short-term assets is a major determinant of the ability of a small business to draw upon the commercial banks. Some lines of business are denied access to the banking system because their assets are not considered adequate collateral. The great variety of loans made by the banking system to small business at once illustrates the extent to which the financial system has gone in accommodating it and the lengths to which small businesses are sometimes pressed to secure funds.

In general, the types of credit available from banks are more extensive in large than in smaller cities, chiefly because of the dominance of the very large banks in large cities. The different forms of credit available fall off sharply with the size of bank. ${ }^{10}$ The smaller ones are equipped to handle a smaller variety of loans. Thus, borrowers in large cities enjoy a certain advantage in dealing with banks capable of offering a wider range of loans.

${ }^{10} I d$. at 405 . 
In October 1957, approximately half the total volume of loans outstanding and two-thirds of the number of loans were secured loans, but the proportions were heavier than this in the smaller-borrower categories. Over seventy-eight per cent of the dollar value and sixty-eight per cent of the number of loans to borrowers with assets of $\$ 50,000$ and under were secured. Both the percentages of dollar volume and the number of loans which were secured declined steadily with larger borrowers. For firms with $\$ 100,000,000$ and more of assets, only seventeen per cent of the value and thirty-five per cent of the number of loans were secured.

Data are available on the security for bank loans; we do not have information on the maturity distribution of loans by type of security. There are certain types of secured loans which have short-term maturities. They are:

a. Loans on consumer paper. Over three-fourths of a sample of banks interviewed in a recent Federal Reserve System survey of credit and capital sources ${ }^{11}$ reported common usage ${ }^{12}$ of loans to small business on consumer paper. It seems especially prevalent in smaller banks, and is used, of course, in large part by retail businesses. Auto dealers sell consumer paper to banks regularly too, but not all banks make such loans. Contract terms vary widely, including purchase with and without recourse, repurchase agreements, and other particular stipulations. Equipment dealers sell the paper arising from purchase contracts too, most frequently to medium and larger banks in small and medium-sized communities.

b. Construction loans. Construction loans are extended by fewer banks than are loans on consumer paper. Smaller banks in small communities rarely engage in this type of loan. Apparently the technique is not familiar to them, and the loans require more supervision than the smaller banks are equipped to give. Loans are usually made only to borrowers with established deposit relationships. Maturities range widely, but average in the neighborhood of six months.

c. Inventory loans. Inventory loans are made frequently by only slightly over half the commercial banks. This is a rather specialized form of lending, involving considerable administrative expense and difficulty. Thus, large banks, with a more extensive administrative apparatus, are more frequent handlers of this type of loan. Businesses get credit for periods extending from demand to one year; the terms average one-half year.

Continuity of markets and reasonable price stability are necessary to make inventory usable as loan collateral. Unfinished or semifinished inventory is generally not acceptable, nor is any item whose resale value is not easily determined. Hence, borrowing on inventory is confined largely to industries whose inventory is readily resalable. Consumer durable goods sellers, including automobiles, appliances, and furniture, farm equipment dealers, the food and textile industries, liquor dealers, and dealers in construction materials are the most likely borrowers. Dealers in perishables and specialized products are virtually excluded.

${ }^{11} I d$. at 404 , table 5 .

12 Bankers were asked to respond qualitatively regarding the frequency with which various types of loans were made. The categories were "frequently, occasionally, rarely, or never." Id. at 403 . 
d. Accounts receivable financing. This is an increasingly popular type of loan, but as yet, it is made less frequently than any of the three types mentioned above. It is comparatively new to the banking system, which shunned the risk and administrative problems inherent in it for a long time. The success of commercial finance companies in handling this kind of credit spurred its adoption by the banks. Also, it has been asserted that the passage of the Assignment of Claims Act by Congress in 1940, which permitted the assignment of claims against the Government, and lending on this security by the RFC added to the acceptability of this kind of financing, ${ }^{13}$ which has been often thought of as stemming from precarious financial circumstances. The V-loan program during the war often involved securing loans by receivables too, and this may have played a role in its spread. Debtors on accounts receivable frequently dislike having their obligations transferred without their knowledge. It has been alleged that the increase in popularity of statutes requiring filing notice of intent to assign accounts has dispelled the stigma of secrecy surrounding the practice ${ }^{14}$ and contributed to its growth. Another suggestion is that the pressure of excess reserves in commercial banks during the 1930 's forced them to search widely for earning assets, and this kind of loan grew in consequence.

Accounts receivable are assigned to the banks as security in this type of lending, but usually the debtor on the accounts is not notified; he pays the seller of goods as he would otherwise, and the payment is forwarded to the bank. Security of the loan rests upon the collectibility of the underlying accounts receivable. Hence, the banker carefully examines the size, age, diversification of the accounts, and the credit standing of the various debtors. Unlike commercial finance companies and factors, banks have no minimum size requirements of a customer's business necessary to qualify for financing, nor a maximum of a customer's total receivables they will finance. Typically, they will advance seventy-five per cent of the face value of the receivables, but this is dependent on rates charged and varies with individual circumstances.

Credit insurance is an old, but little known, device which seemingly could enhance the ability of small firms to borrow upon the security of their accounts receivable. It protects against bad-debt losses in excess of the normal or primary loss rate experienced by the firm in its past. Two companies are writing this type of insurance in the United States at present, covering an estimated $\$ 8,000,000,000$ of sales annually. ${ }^{15}$

It seems probable that commercial banks would be more willing than otherwise to lend upon the security of insured accounts receivable, and similarly for commercial finance companies. Indeed, it is possible to obtain riders for these insurance policies allowing the client's bank to file claims against the insurance company.

\footnotetext{
${ }^{13}$ Zinner, The Contribution of Commercial Receivable Companies and Factors to Financing Small-and Medium-Size Business, 2 J. Finance 88 (1947); Clyde William Phelps, Accounts Receivable Findncing As a Method of Business Finance 61 (1957). Cf. 54 Stat. 1029, 41 U.S.C. \$ 15 (1952).

14 Credit Policy Commission, American Bankers Association, Accounts Receivadle financino 2 (1957).

${ }_{15}$ Cloos, Credit Insurance, in Federal Reserve Report 480.
} 
However, it is possible for banks to construct their loans to give recourse against the creditor in the event of default upon a receivable, and this is regularly a feature of commercial finance company nonnotification financing. Nevertheless, such insurance should add to the ability of a marginal risk firm or a firm with undiversified or otherwise unsuitable accounts receivable to use them for collateral.

\section{Size and industry of borrowers: economic fluctuations}

Fluctuations in the aggregate level of business activity and in the pattern of demand for final products affect the magnitude and direction of bank borrowing. The industry-size-of-business distribution of loans underwent substantial alteration during the boom in business activity and stringency in the financial markets in the period I955-57, as is shown in table four. In these two years, total loans to business had expanded by $\$ 9,800,000,000$, but the industry and size groups of businesses shared unevenly in the expansion. In general, large businesses experienced loan growth disproportionate to their percentages of loans outstanding at the beginning of the period. In October 1955 , small businesses in all industries had twenty-one per cent of

\section{TABLE IV}

Distributton of the InCRease of Business Loans of Member Banks, 1955-57, by Business and Relative Size of Borrower ${ }^{1}$

\begin{tabular}{|c|c|c|c|c|}
\hline \multirow{2}{*}{ Business of Borrower } & \multirow{2}{*}{$\begin{array}{l}\text { Increase } \\
\text { (millions of } \\
\text { dollars) }\end{array}$} & \multicolumn{3}{|c|}{ 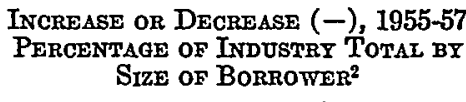 } \\
\hline & & Small & Medium & Large \\
\hline 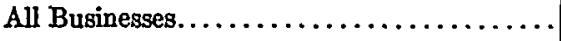 & $\$ 9813$ & 6.9 & 39.5 & 50.4 \\
\hline 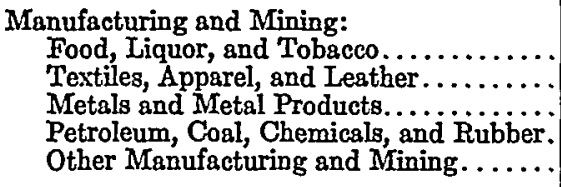 & $\begin{array}{r}523 \\
-53 \\
2285 \\
1147 \\
895\end{array}$ & $\begin{array}{r}10.0 \\
-154.4 \\
16.6 \\
13.0 \\
2.1\end{array}$ & $\begin{array}{r}6.2 \\
-95.3 \\
32.0 \\
14.5 \\
58.9\end{array}$ & $\begin{array}{r}83.7 \\
157.1 \\
51.4 \\
68.0 \\
38.0\end{array}$ \\
\hline $\begin{array}{l}\text { Trade: } \\
\text { Retail Trade. } \ldots \ldots \ldots \ldots \ldots \ldots \ldots \ldots \ldots \ldots \\
\text { Wholesale Trade. } \ldots \ldots \ldots \ldots \ldots \ldots \ldots \ldots \\
\text { Commodity Dealers. } \ldots \ldots \ldots \ldots \ldots \ldots\end{array}$ & $\begin{array}{r}1144 \\
590 \\
79\end{array}$ & $\begin{array}{r}1.4 \\
16.0 \\
7.4\end{array}$ & $\begin{array}{l}56.9 \\
48.4 \\
12.7\end{array}$ & $\begin{array}{l}38.9 \\
37.2 \\
78.7\end{array}$ \\
\hline 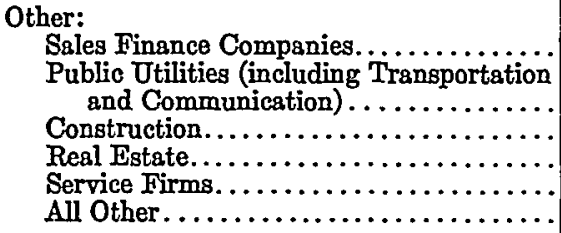 & $\begin{array}{r}263 \\
1334 \\
289 \\
546 \\
499 \\
272\end{array}$ & $\begin{array}{r}-2.7 \\
1.1 \\
-\quad 3.5 \\
4.1 \\
2.8 \\
2.1\end{array}$ & $\begin{array}{l}74.9 \\
53.6 \\
27.9 \\
23.5 \\
56.7 \\
41.7\end{array}$ & $\begin{array}{l}27.1 \\
39.7 \\
62.8 \\
52.6 \\
41.4 \\
46.5\end{array}$ \\
\hline
\end{tabular}

1 For classification of borrowers by size, see supra note 4 in the text.

2 Figures do not sdd to $100 \%$, bewuse some loans were made to borrowers whose size was not ascertained.


Bunu, Business 371, 375 (Comm. Print 1958). 
the loans outstanding; medium-sized borrowers had forty-five per cent; and large ${ }^{10}$ borrowers, thirty-two per cent. In the expansion of the following two years, however, small businesses in all industries got slightly less than seven per cent of the increase, while medium-size businesses claimed almost forty per cent, and large businesses over half.

Changes in the demands for final products played a significant role in the pattern of bank lending to small business. Industries dominated by large firms received the largest part of the banks' loan growth in this period. The following industriesmetals and metal products, petroleum, coal, chemicals, rubber, and public utilitiesreceived over half the expansion in loans to large businesses. This concentrated growth is attributable to several factors: ${ }^{17}$ (I) in general, large businesses account for a preponderance of output in these industries; (2) these industries experienced some of the largest increases in demand for their final products in this period, some of the greatest increases in output, and also, with the exception of public utilities, some of the sharpest rises in product prices; and (3) capacity, including working capital, was expanded sharply in these three industries.

A large part of the working-capital growth of large corporate bank borrowers was represented by an increase of net accounts receivable. Since large corporations tend to be net creditors of smaller corporations and the unincorporated universe, this growth of net receivables may have served as financing for the latter in place of added bank borrowing.

In the retail trade, small firms received an extremely small part of the industry's total growth in loans, but medium-sized firms received almost fifty-seven per cent of the increase. In the wholesale trade, small firms received sixteen per cent of the industry's loan increase. In the services industry, medium-sized firms, again, received well over half the industry's expansion, and firms in the smallest size bracket claimed an almost negligible share.

Small firms in construction and textiles, leather, and apparel actually experienced declines in loans outstanding. The situation in construction in this period is explained by a decline in home building, in which small firms predominate, and an increase in industrial and commercial construction projects, often suitable only for large firms. Over-all depression of activity is probably responsible for the net decline of bank loans to small firms in the textile industry. Indeed, the industry total of bank borrowing declined in this period.

\section{B. Other Intermediaries and Governmental Sources}

A certain volume of funds are procured from other intermediaries by small businesses through the use of collateral unrelated to the business. We know little of its ultimate use that is definite, but it seems certain that some is devoted to short-

${ }^{28}$ Again, we are employing size definitions of the Federal Reserve Board, and they differ according to the size pattern of enterprises characteristic of that industry. See Eckert, Member Bank Lending to Small Business, 1955-57, FEDERAL RESERVE REPORT 371.

${ }^{17} 1 d$. at 379 . 
term purposes. The most significant of these intermediaries are the mortgage lenders. Small businessmen faced with great difficulty in securing funds from the banking system and the specialized financing institutions sometimes mortgage their residential real estate to life insurance companies or savings and loan associations, and utilize the funds gained in their businesses. ${ }^{18}$ Similarly, a certain portion of the policy loans made by life insurance companies ultimately is used by small businesses for short-term purposes. Again, however, we have almost no quantitative information. It has been pointed out ${ }^{19}$ that the volume of reserves held against life policies by the insurance companies appears to be a source of funds ill-developed by small business. At the end of 1956 , for example, outstanding policy loans represented only six per cent of the reserves maintained to guarantee fulfillment of life insurance contracts. The interest rate on policy loans is contractual, and its differential from other money rates becomes favorable in times of tight money; yet, the volume of loans outstanding is not sensitive to interest-rate fluctuation.

A certain portion of the bond and commercial mortgage loans made by life insurance companies goes to small businesses. The volume going to a small business, however, is not significant and is predominantly long-term in character. The annual dollar volume of loans less than $\$ 250,000$ in size was $\$ 278,000,000$ for the period $1953-56$ by life companies controlling seventy-seven per cent of the industry's assets. The web of state laws surrounding investments by the life insurance companies prevents them from becoming lenders to small business, and there is little prospect of a fundamental change in this situation.

A number of governmentally-sponsored small business loan programs have been adopted at times in the past, and some continue now..$^{20}$ Most of these programs have made available medium-term loans. The programs have attempted to make funds available for working-capital purposes. Federal Reserve loans to businesses were confined by statute to working-capital purposes. Roughly one-third of the loans made by the RFC were used for this purpose, and thirty-six per cent of the loans authorized by the Small Business Administration have been for working capital. Quantitatively, the contribution of governmental loan programs to small business has not been large. The combined volume of SBA and VA business loans and commitments outstanding at the end of 1955 was equal to only two per cent of the small business loans outstanding at member banks.

\section{Interbusiness Financing}

Interbusiness financing is the extension of credit by one nonfinancial business to another, usually from seller to buyer. ${ }^{21}$ Merchandise vendors often view credit

${ }^{18}$ Life Insurance Association of America, Survey of Life insurance Loans to Business and INDUSTRY 5, table 2 (Joint Investment Bull. No. 321, 1957). See also Klaman, Life Insurance Companies, in Federal Reserve Report 512, 518.

${ }^{10}$ Andrews, Friedland, and Shapiro, Who Finances Small Business?, in Federal Reserve Report 20, 34.

${ }^{10}$ For a comprehensive review of governmental programs, see Arlt, Governmental Loan Programs for Small Business, in Federal Reserve Report 253.

${ }^{22}$ Einzig, Credit from Large to Small Business, in Federal Reserve Report $482,483$. 
to a small business more sympathetically than financial institutions. One reason for this is that the selling firm expects to stimulate sales by extending credit, relying on added profits to offset the risk and costs of the loan. Another explanation is that the seller may have to choose between financing independently-owned distributors or operating his own distribution system. Should he choose the latter, he may have to supply the bulk of the operation's financial requirements as well as shoulder the nonfinancial risks entailed in the operation of the integrated distribution system. In much of trade credit, the cash expenditure of the seller is less than the credit received by the buyer, because the price of the merchandise includes profit and noncash expenses, such as depreciation.

Most interbusiness financing takes the form of trade credit, in which merchandise is sold on credit terms, with only a ledger account to indicate the debt. Other forms include merchandise sales where customer indebtedness is evidenced by notes or trade acceptances, customer's receivables or installment paper, "floor plan financing" of inventory in dealer's hands for periods longer than ordinary trade credit, and advance payments to suppliers for merchandise.

\section{Trade credit}

a. The volume of trade credit. Accounts receivable are a reasonably accurate measure of credit extended, and accounts payable contain mainly trade debt, and, therefore, we can look upon them as gauges of the volume of trade credit outstanding. Table five presents trade payables as a percentage of all sources of funds for various classes of firms. The data show that manufacturing corporations depend more heavily upon trade credit than does the corporate universe, and, more significant for our discussion, that small firms are more dependent upon trade credit than are large.

\section{TABLE V}

Accounts Payable for Nonfinancial Corporations and Manufacturing Corporations, by Size of Firm, and for the Nonfarm, Noncorporate Business Sector

\begin{tabular}{|c|c|c|}
\hline & \multicolumn{2}{|c|}{ Accounts Payable } \\
\hline & \$ Billions & $\%$ of Total Liabilitie \\
\hline $\begin{array}{l}\text { All Nonfinancial Corporations } \\
\text { Nonfinancial Corporations with Assets } \ldots \ldots \ldots \ldots \ldots \ldots\end{array}$ & $\$ 40.0$ & $\begin{array}{l}14.8 \% \\
31.5\end{array}$ \\
\hline All Manufacturing Corporations ${ }^{2} \ldots \ldots \ldots \ldots \ldots \ldots \ldots \ldots \ldots$ & 15.8 & 23.6 \\
\hline Manufacturing Corporations with Assets Less than $\$ 250,000^{2}$. . & 1.2 & 45.6 \\
\hline Nonfarm, Noncorporate Business Sector ${ }^{3}$. & 11.0 & $19.8^{4}$ \\
\hline
\end{tabular}

1INTERNaI, Revenue Seatice, Statistics of Ircoug pt. 2 (1955).

2FTC-SEC Quarterly FinancialReport for Manufacturing Corporations, 4th quarter 1955

343 FED. REs. BOLL. 1194 (1957).

SThe nonfarm, noncorporate sectr includes dats for unincorporated real estate firms and individuals with real estato portfoliog. As a result, mortgages for the entire sector account for $\$ 25,800,000,000$, or $46 \%$ of total liabilities. While it is impossiblo to distinguish betwern mortgages held by real estate firms and the mortgages of the properties of other unincorporated firms, the real cstato group undoubtedly acconnts for the bulk of mortgares. If the martgages nlus $\$ 3,200,000000$ of bank loans made to unincorporated real cstato firms aro remove rom the sector, accounts payable become $41.4 \%$ of the remaining liabilities. 
While trade credit is the most important short-term source of funds for the universe of manufacturing corporations, it is only slightly larger than accrued taxes. However, for manufacturing firms with assets less than $\$ 250,000$, trade credit is about four times larger than the second most important short-term source. For noncorporate, nonfarm businesses, trade credit and bank credit are about equally important, after the adjustment for unincorporated real estate firms, shown in note four, table five.

In the decade following World War II, trade credit was about four per cent of the total sources of funds of the Federal Reserve Board's sample of 300 large corporations. In contrast, trade credit constituted about thirteen per cent of the total sources for all other corporations. ${ }^{22}$

b. Trade credit and size of firm. The ratio of trade receivables to trade payables is a measure of the extent to which a firm is a net trade creditor. If the firm receives more trade credit than it extends, payables will exceed receivables and the ratio will be less than one, and conversely. Between $195 \mathrm{I}$ and r957, all manufacturing corporations were net trade creditors. The ratio of receivables to payables averaged 1.8 over the period. ${ }^{23}$ However, except for firms with assets in excess of $\$ 100,000,000$, the receivables/payables ratio declined with the size of firm. For example, manufacturing firms with assets less than $\$ 250,000$ had a receivables/payables ratio of only r.2 over the period.

A recent analysis of the receivables/payables ratio by industry and firm size for the corporate universe indicates that trade credit tends to flow from large firms to small firms. ${ }^{24}$ Very small firms, and, undoubtedly, most unincorporated enterprises are net trade debtors. These findings are consistent with the thesis that large firms effect a transfer of funds between the capital markets and small enterprises.

During the period $x 95457$, bank credit was tightened. At the same time, and perhaps as a result, the proportion of high-risk loans made by banks decreased. The industries most strongly affected were trade, construction, and textiles, which are composed primarily of small firms. ${ }^{25}$ Thus, although bank credit was made less accessible generally, it appears that the small firms were rationed more severely than large ones.

During this period of stringency in the supply of funds from the banking system, trade credit expanded. Data in the Quarterly Financial Report for Manufacturing Corporations showed a substantial increase in net trade credit during 1955 and $195^{6.6}$ The increase in trade credit extended by manufacturing corporations exceeded the increase in bank loans. Firms drew down cash balances to increase the volume of

${ }^{22}$ Andrews, Friedland, and Shapiro, supra note ig at 23.

${ }^{23}$ FTC-SEC Quarterly Financial Report for Manufacturing Corporations, 4th $^{\text {th }}$ quarter 195I-4th quarter 1957.

24 Trade Credit: A Factor in the Rationing of Capital, Monthly Review of the Federal Reserve Bank of Kansas City, June 1957, p. 3.

${ }^{26}$ The Price of Business Loans, Business Conditions, Monthly Review of the Federal Reserve Bank of Chicago, March 1957, p. 14.

${ }^{20}$ Trade Credit: $A$ Factor in the Rationing of Capital, supra note 24, at 5. 
trade credit. The velocity of money was raised in this way to offset stringency in the money supply. More current data indicate that in 1956 , large corporations (trade credit suppliers) increased both bank loans and long-term indebtedness more rapidly than they had in I955. Small corporations, on the other hand, increased bank loans less in 1956 than in 1955 and decreased the level of long-term indebtedness. In 1955, trade credit represented a use of funds for small corporations-i.e., small corporations extended more trade credit than they received. In 1956 , trade credit was the single most important source of funds for the small corporations.

The behavior of trade credit during this period confirms earlier studies ${ }^{27}$ which suggest that larger firms tend to distribute the total supply of funds in the business sector and, thereby, add liquidity to smaller enterprises. The data lend credence to the interposition view of the financial system.

\section{c. Trade credit terms}

(I) Availability. On occasion, minimum orders are required before credit terms are made available. ${ }^{28}$ These requirements are usually set low enough as not to bar small business. To assure the seller a practicable amount of business, the requirements may be a minimum purchase order or a minimum level of total sales.

Almost all customers are screened for credit-worthiness before trade credit is extended. However, the standards applied are flexible, since the credit risk is associated with a profitable sale. The credit check involves the use of rating services such as Dun and Bradstreet, the buyer's history with trade credit, statement analysis, personal contact, and the buyer's relationships with commercial banks. Most firms are willing to grant some trade credit to new customers, but restrict the amount until experience has been gained.

(2) Maturity. The typical maturity for trade credit is thirty days, but a number of factors cause variations in terms. The ability of a businessman to finance inventory through trade credit depends upon the inventory-turnover period and the length of time credit is extended. If the trade credit maturity equals the inventory-turnover period, the seller supplies the inventory-financing needs of the buyer. If the maturity falls short of the inventory-turnover period, the buyer must finance inventory from other sources for the remainder of the turnover period. If the maturity exceeds the inventory-turnover period, trade credit will finance all inventory needs and be available for other working-capital purposes. Analysis of data from the Robert Morris Associates shows considerable variation in the relationship between credit maturity and inventory-turnover periods in various industries. For example, meat is sold on maximum credit terms of five days, while blanket sales in an off-season period may carry credit for as long as six months.

\footnotetext{
${ }^{27}$ Jacoby \& Weston, Financial Policies for Regularizing Business Investment, in Regularization or Business Investment 369 (1954); C. L. Merwin, Financing Small Corporations in Five Manufacturing Industries (1942); J. K. Butrers \& J. Lintner, The Effects of TAxes on Growino EntenPRISES (I945).

${ }^{28}$ The material in this section is taken from Einzig, supra note $2 \mathrm{x}$, at 484 .
} 
Competition plays a role in determining the length of trade credit. During periods of strong competition among sellers, trade credit maturities tend to be lengthened. Also, industries characterized by a large number of firms, such as apparel, leather, and furniture and fixtures, extend lengthier terms than industries characterized by fewer sellers, such as petroleum, chemicals, rubber, and iron and steel. An alternate explanation of this phenomenon may be that those industries with few sellers have large customers with minimal trade credit needs.

Because of the relationship between trade credit extension and profitable sales, the maturity of trade credit is not as sternly enforced as it would be by a purely financial institution.

(3) Costs of and returns on trade credit. The costs of trade credit are bound up with its maturity. If payment is made within a specified time, discounts may be taken by the buyer. Although discount terms vary from none in the food and dairy industry to as high as eight per cent in the apparel industry, the most widely quoted rate is two per cent. In order to deduct the discount, the bill must be paid generally within ten or fifteen days. For example, credit terms may be $2 / \mathrm{ro}, \mathrm{n} / 3^{0}$, which means that a two per cent discount may be taken if the bill is paid within ten days, but the gross bill must be paid within thirty days. Failure to take the discount is costly. If the buyer waited thirty days to make payment, he would forego a two per cent discount for an additional twenty days of credit, the equivalent of a thirtysix per cent interest rate. However, if the gross maturity were more generous, the cost of foregoing the discount would fall. If the terms were $2 / \mathrm{ro}, \mathrm{n} / 60$, and the buyer waited sixty days before paying the bill, the cost would be equivalent to a 14.4 per cent annual interest rate.

Although there is variation in credit terms among sellers, most do not discriminate among customers. However, hearsay evidence indicates that credit terms are allowed to vary from formal quotations on occasion. There are many ways for such deviations to occur, but the simplest is when the seller allows a cash discount after the discount period or even after the gross maturity date. This is more subtle competition than price cuts or changes in quoted credit terms, since competitors may be unaware of the change for a time and unable to respond quickly.

Other credit costs may be included in the price of the goods. Since the seller has incurred credit costs (ranging from the interest cost of borrowed funds to the loss of the return from an alternate use of the funds), these may be embedded in the price charged for the product. However, the increase in sales resulting from the extension of trade credit may allow the seller to achieve significant economies of scale or to reduce his inventory storage costs. In this event, the resulting savings may absorb the added costs of extending credit.

That savings may accrue to the seller from the extension of trade credit is indicated by the existence of deferred dating practices. Deferred dating applies usually to seasonal items in which off-season purchases are accorded credit terms for as long as six months. In the sporting goods industry, for example, goods shipped after 
December I could be for and discount taken to April ro; if shipped after June I, discount could be taken to October Io; and if shipped between October I and December I, discounts could be taken to January Io. The savings which tend to offset the seller's credit costs are the removal of seasonal variations in production and the reduction of inventory storage costs, as well as increased sales. In nonseasonal goods, deferred datings are used to work off excessive inventories and to encourage large orders.

\section{Receivables financing and "floor planning"}

Financing the buyer's credit sales and inventory needs through the extension of credit by the seller with accounts receivable or inventory as security has grown rapidly. ${ }^{29}$ Receivables financing and "floor planning" (financing with customer's inventory as security) are done almost exclusively by very large suppliers. Direct receivables financing is done in the petroleum industry through the financing of consumer credit cards, gasoline sales to farmers, and bulk fuel oil receivables. In the machinery industry, dealers who offer rental or installment terms to their customers have the resulting receivables financed by the manufacturer.

a. Financial subsidiaries. Increasingly, companies which engage in accounts receivable financing or "floor planning" do so through a financial subsidiary. It has been estimated that since 1949 , fifty financial subsidiaries of nonfinancial companies have been organized. Almost all the parent companies are among the 500 largest industrial firms. ${ }^{30}$ Most of the subsidiaries specialize in financing the sale of hard goods, such as motor vehicles and electrical appliances.

Initially, financial subsidiaries are financed largely by the parent company. However, after several years of successful operation, the subsidiary can usually turn to the financial markets on the basis of its own credit standing. Since the business of the subsidiary is related to the sales of the parent firm, the financial subsidiary enjoys an excellent credit rating and has access to funds on favorable terms.

The "floor planning" activities of financial subsidiaries result from an attempt by the selling firm to supplement ordinary trade credit terms in order to finance the customer's entire inventory-turnover period. Regular "floor planning" is usually not done for more than a nine-month period, although renewals are common when merchandise has not been sold. ${ }^{31}$ In financing receivables, the time period is ordinarily much longer, averaging three years, ${ }^{32}$ and ranging up to seven years for the heavier durable items.

These credit devices are clearly for competitive purposes and are apparently highly successful. ${ }^{33}$ The use of the subsidiary reduces the risk to the parent which would result from financing these longer-term needs of customers directly or indirectly.

${ }^{20} 1 d$. at 489 .

${ }^{30}$ Banner, Competition, Credit Policies, and the Captive Finance Company, 73 Q. J. EcoN. 24x, 242 (1958).

${ }^{31}$ Einzig, supra note $2 \mathrm{I}$, at 490.

s2 7 bid.

ss Banner, supra note 30 , at $243-48$. 
While this result could be achieved through arrangements with an independent finance company, the subsidiary can be depended upon to operate with the primary aim of expanding the parent's sales. The independent finance company is more apt to be concerned with the credit-worthiness of the customer. ${ }^{34}$ There is also evidence indicating that the financial subsidiaries generate substantial profits to the parent companies purely from financing charges. ${ }^{35}$

\section{Other forms of interbusiness credit}

Other short-term credit devices are largely restricted to marginal credit risks, who, upon receipt of goods, are required to sign formal debt instruments as trade acceptances and notes. ${ }^{36}$ However, in some industries, such as furniture and canning, trade acceptances are used for most credit transactions.

Both notes and trade acceptances run typically for ninety days and carry interest rates from five to six per cent. They are also used when trade credit accounts become overdue, or when a customer desires credit above his trade credit limit. Sellers feel that the formal instrument creates more pressure for prompt repayment than does an open book account, as well as constituting a superior legal claim. By and large, notes are used more frequently for these purposes than are trade acceptances.

\section{Social issues}

As was pointed out above, interbusiness financing tends to flow from large (sellers) to smaller (buyers) firms. Since large firms have a financial advantage over smaller firms in securing funds, the existence of interbusiness financing may pose a threat to competition by enabling the larger firm to undercut (either on price or credit terms) the smaller firms which are in direct competition with it. On the other hand, in the customer markets, small firms may not be able to survive in the absence of interbusiness financing. Thus, if trade credit were abolished to improve competition on the sellers' side, it might result in a concurrent decline in competition on the buyers' side by reducing the number of small firms whose existence is dependent upon the availability of trade credit.

\section{Financing through Commercial Finance Companies and Factors}

Commercial finance companies and factors are important to small business, both because of the volume of financing they handle and because they make funds available to some businesses unable to draw upon the banking system. The bulk of their activity involves the purchase or lending on the security of accounts receivable, sometimes referred to as "credit at the margin" or "lending at the margin." The large finance companies, on the other hand, have access to the nation's financial markets on terms relatively more favorable than their customers. They draw heavily upon the open commercial paper market, and in addition, the large finance companies place

${ }^{36}$ Id. at 249-50.

${ }^{36}$ Id. at 253 .

${ }^{20}$ Einzig, stura note 2I, at 490. 
paper privately; they are preferred borrowers from the banking system with faultless credit records, and they draw heavily on the corporate bond market. Thus, they are wholesalers of funds.

There are several types of specialized finance companies which lend to consumers, to businesses whose customers are consumers, and to businesses whose clients primarily are other businesses. Commercial finance companies and factors engage in the last-named type of financing, and we concentrate upon it here.

Commercial finance companies and factors make short-term funds available through lending on, or the purchase of, open book accounts receivable and on inventory loans. They also make an important and growing volume of funds available for equipment financing, but this is not short-term financing. Commercial finance companies lend or advance money, typically eighty per cent of the face value, on the security of assigned accounts receivable, without notice to the obligor and without assuming risk or the task of collecting on the account. The debtor on the account receivable makes payment in the ordinary way to the seller of goods, who, in turn, pays the finance company. "Factoring" is the outright purchase of accounts receivable, without recourse to the seller and with notice to the obligor, who then pays the factor directly. Here, the risk of default and the job of collection is absorbed by the factor. Again, these functions are generally performed by separate companies, but the separation is not hard and fast. Several companies regularly offer both sorts of arrangements. Accounts receivable financing is not a one-time loan, but involves a continuing relationship between the borrower and the institution, because loans and advances are made on a revolving basis as each sales invoice is assigned or sold, usually daily. The underlying security is the strength of the receivables themselves, and, hence, the finance companies exercise surveillance over the borrower's operations including audits and managerial assistance.

Inventory loans are made almost invariably to regular customers of the accounts receivable trade on the strength of warehouse receipts, factors' liens, and trust receipts. This lending is confined to finished goods and resalable raw materials inventory and excludes goods-in-process. Inventories are usually less desirable collateral for loans than receivables because of the drastic price reductions involved in forced liquidation.

Comprehensive statistics of the number of borrowers and the volume of financing are not available. Estimates indicate that perhaps less than 20,000 firms, with assets between $\$ 350,000$ and $\$ 650,000$, are regularly financed directly by these institutions. ${ }^{37}$ A sample of thirty of the largest institutions had $\$ 512,000,000$ of accounts receivable outstanding at the end of 1956 , and the volume for the year was $\$ 4,600,000$,000 on 3,744 borrowing arrangements. ${ }^{38}$

Carrying accounts receivable freezes a firm's funds during the collection period. Receivables financing eliminates the wait for the normal process of turnover to liquidate the account. Thus, the turnover of receivables in the portfolios of finance

\footnotetext{
${ }^{37}$ Pawley, Survey of Commercial Finance Companies and Factors, in Federal Reserve Report 449.

${ }^{38} I d$. at $45 \mathrm{I}$.
} 
companies and factors is one measure of the contribution made in financing small firms. The average turnover period based on sales in the thirty-company group was 32.4 days in 1956 for loans on receivables, and 43.I days for factored receivables.

Several features of the operations of commercial finance companies and factors give small businesses in manufacturing and the wholesale trade better access to this financing than others have. Concerns in these lines usually have products with stable markets, they have average sales invoices of substantial amounts, and they sell primarily to other businesses rather than to consumers. These characteristics give the lender security for his loan and make for transactions sizable enough to be profitable. Firms in the retail industry, however, are virtually excluded because of the absence of the aforementioned features in their operations, and we have seen earlier that over two-fifths of the entire business population centers in the retail trade. Receivables of service organizations are unacceptable, because the product is intangible and the collateral value of the receivable less certain as a result. Construction firms are normally precluded from borrowing against receivables because mechanics' liens and the danger of nonperformance by contractors vitiate the collateral value. Within the two major types of clientele ${ }^{39}$ (manufacturing and wholesale trade), there is not a dominant kind of business; firms in an immense variety of product lines use finance companies.

Factoring, on the other hand, is used for the most part by firms in textiles, though in recent years it has spread beyond this industry. The notification feature of factoring appears to limit its spread somewhat, because a great deal of prejudice against it remains among trade customers who apparently prefer strongly to deal only with the vendor or who believe the practice connotes financial difficulties for the vendor. Small invoices and receivables with an uncertain security status, such as receivables in the construction and service industries, are excluded from factoring, as they are from open accounts receivable financing.

Minimum size requirements limit the ability of many small firms to utilize finance companies and factors. Clearly, a certain volume of business is requisite to make an account a paying proposition for the lender; and, consequently, these institutions impose minimum sales requirements, and/or requirements for minimum amounts of credit outstanding, and occasionally minimum net worth standards. Minimum size requirements are not inflexible. If a finance company has reasonable assurance that a firm will grow into a profitable customer, it frequently will extend not only financing, but also managerial advice and assistance. Moreover, size requirements differ as between size of finance company, with the larger specifying higher volume requirements.

\section{SUMMARY}

This paper has been concerned with the nature of the industry demands for short-term funds and the various sources from which these demands are met. We have elaborated upon the numerous segments of the market for short-term funds

${ }^{30} \mathrm{Id}$. at 454 . 
to which small business has access. Of even greater importance, we have tried to demonstrate the progressive development and extension of lending institutions and practices which reduce the credit risk posed by the small borrower by utilizing as loan security those assets which small firms have in relative abundance.

Our examination of the availability of short-term funds to small business lends weight to the conclusions ${ }^{40}$ of others that the short-term needs of these businesses are being met in a relatively satisfactory way.

${ }^{10}$ See particularly the testimony of A. D. H. Kaplan, A. F. Maxwell, H. L. Thomas, and W. McC. Martin, in Hearings Before a Subcommittee on Small Business of the Senate Committee on Banking and Currency on the Credit Needs of Small Business, 85th Cong., Ist Sess. 93, 128-29, 179, 500 (1957). 